\title{
PERAN KOMUNIKASI INTRAPERSONAL SEBAGAI SELF HEALING
}

\author{
Yogi Noviariski ${ }^{1}$
}

\begin{abstract}
The purpose of this research is to reveal the role of intrapersonal communication as self healing. The method used in this research is qualitative with the type of literature study. Information is the main key in life, the information is received by the self through intrapersonal communication. Intrapersonal communication is also a cause and effect for social, cultural and even human health. As self healing, intrapersonal communication can be done by instilling positive thoughts. Positive thoughts can stimulate cells in the body so that they can become self-healing for humans. Negative information can also be coded into positive things if we are able to change it through positive thoughts. In order to be able to become self-healing, we can instill positive information through affirmation techniques and not vice versa. Because if we do the opposite, we will kill the cells in the body.
\end{abstract}

Keyword: Intrapersonal Communication; Mind; Self Healing;

\begin{abstract}
Abstrak
Tujuan penulisan penelitian ini ialah untuk mengungkap bagaimana peran komunikasi intrapersonal sebagai self healing. Metode yang digunakan pada penelitian ini ialah kualitatif dengan tipe studi pustaka. Informasi merupakan kunci utama dalam kehidupan, informasi tersebut diterima oleh diri melalui komunikasi intrapersonal. Komunikasi Intrapersonal juga merupakan sebab akibat bagi kehudpan social, budaya bahkan kesehatan manusia. Sebagai self healing komunikasi intrapersonal dapat dilakukan dengan cara menanamkan pikiran positif. Pikiran positif dapat merangsang sel-sel didalam tubuh sehingga mampu menjadi penyembuh (self healing) bagi diri manusia. Informasi yang negatif juga dapat di kodekan menjadi hal positif apabila kita mampu mengubahnya melalui pikiran yang positif. Agar mampu menjadi self healing, kita dapat menanamkan informasi positif melalui teknik afirmasi dan jangan sebaliknya. Karena apabila yang sebaliknya kita lakukan maka kita akan membunuh sel-sel di dalam tubuh.
\end{abstract}

Kata kunci: Komunikasi Intrapersonal; Pikiran; Self Healing;

\footnotetext{
${ }^{1}$ Magister Ilmu Komunikasi, Fakultas Ilmu Sosial dan Ilmu Politik, Universitas Bengkulu Jalan WR. Supratman, Kandang Limun, Kec. Muara Bangka Hulu, Bengkulu 38371 E-mail: yogi.d1e014024@gmail.com
} 
Volume 2, Nomor 2, Desember 2021

\section{PENDAHULUAN}

Komunikasi merupakan hal yang tidak dapat ditinggalkan oleh manusia sebagai makhluk sosial. Komunikasi selalu ada di setiap kegiatan manusia, baik saat bersama orang lain maupun saat sendirian. Proses berpikir, merenung, meditasi dan lain merupakan salah satu bentuk komunikasi kepada diri sendiri (intrapersonal). Namun, terkadang banyak yang tidak menyadari bahwa mereka sedang melakukan sebuah komunikasi karena komunikasi sering dihubungkan dengan dua orang atau lebih saja.

Komunikasi memiliki peran yang sangat penting terhadap prilaku manusia, bahkan komunikasi juga memiliki peran penting kesehatan manusia. "Banyaknya halangan yang ditemui dalam membentuk komunikasi yang efektif antara dokter dan pasien, antara lain pasien merasa cemas yang berlebihan, pasien tidak mampu menerima keterangan dari dokter mengenai bagaimana kondisinya, dokter yang merasa terbebani oleh pekerjaan mereka, pasien tidak menolak menandatangani surat persetujuan tindakan, dan pemikiran pasien yang tidak realistis (Bakić-Mirić NM dalam Tita Menawati \& Hendra, 2015).

Pada dasarnya kebanyakan manusia lebih sering menginterpretasikan komunikasi sebagai bentuk interaksi antara dua orang atau lebih sehingga apa yang dipikirkan, dilamunkan dan diingat mereka anggap bukanlah sebuah komunikasi. Bukan tanpa sebab, karena jika berbicara komunikasi maka tidak terlepas hubungannya dengan manusia sebagai makhluk sosial. Sedangkan dari proses interaksi yang mereka lakukan akan menimbulkan suatu proses sensasi, persepsi, memori, dan berpikir yang merupakan bagian dari komunikasi intrapersonal (Rakhmat dalam Nabilah, 2019).

Self healing merupakan salah satu proses komunikasi intrapersonal dengan cara memberikan ruang dan waktu pada diri kita sendiri untuk menyembuhkan luka batin yang kita alami. Self healing tidak hanya menyembuhkan luka jiwa tetapi juga tubuh kita. Salah satu upaya untuk megurangi kecemasan dapat dilakukan dengan self healing. self-healing merupakan istilah yang menggunakan proses dan berprinsip bahwa tubuh manusia merupakan sesuatu yang mampu memperbaiki dan menyembuhkan dirinya sendiri melalui cara-cara tertentu dan alamiah (Bahrien \& Ardianty, 2017).

Menariknya pada awal kemunculan covid-19 di Wuhan media-media mulai menyiarkan berita mengenai betapa berbahayanya corona virus disease (covid19) bagi kehidupan manusia. Media sosial 
juga seakan tak mau ketinggalan dan ikut menyiarkan berita tentang covid-19. Namun, yang lebih berbahaya daripada covid-19 ialah disinfodemic atau berita bohong mengenai covid-19 itu sendiri. United Nations Educational, Scien- tific and Cultural Organisation (UNESCO) memperingatkan bahwa penyebaran informasi palsu tentang pandemi covid-19 adalah 'bahaya besar' bagi kehidupan banyak orang di seluruh dunia (UNESCO, 2020).

Media pemberitaan sebagai tempat penyebaran informasi yang terpercaya sudah tidak dapat dijadikan sebagai acuan lagi untuk mengetahui mana berita yang benar atau mana berita yang salah. Berbeda dengan pemberitaan media di masa lalu mengenai pandemi, framing berita pandemi COVID-19 bukan hanya tentang tindakan dan konsekuensi. Liputan berita tentang pandemi COVID-19 telah dilakukan berbeda di berbagai wilayah di penjuru dunia. Tetapi ada beberapa tema umum yang dapat ditemukan dalam liputan berita seperti kasus dan tingkat kematian, kepanikan dan ketakutan masyarakat, kesadaran dan pengetahuan terkait penyakit, tindakan pencegahan, perawatan dan biaya, tindakan, kebijakan dan dampak sosial yang lebih luas (Apuke \& Omar, dalam Jamil \& Appiah-Adjei, 2020). Media berita dan jurnalis telah disalahkan karena menyebabkan kepanikan dan ketakutan di tengah masyarakat melalui pelaporan fakta dan informasi yang belum diverifikasi (UNESCO dalam Jamil \& Appiah-Adjei (2020). Ini bisa saja terjadi karena banyak wartawan, terutama di negara-negara berkembang seperti Pakistan, tidak dilatih untuk melaporkan masalah kesehatan dengan akurasi.

Dari uraian di atas dapat disimpulkan bahwa media pemberitaan turut serta sebagai penyebar ketakutan di antara masyarakat di tengah pandemic covid-19. Namun, di sisi lain media pemberitaan dan media massa yang lainnya tidak sepenuhnya dapat disalahkan, karena informasi yang diterima akan melalui proses dari komunikasi intrapersonal yakni sensasi, persepsi, memori, dan berpikir. Jadi, diri sendiri juga turut serta dalam menumbuhkan ketakutan, dan kecemasan di dalam diri selain informasi yang kita terima dari luar. Sebelum seseorang berkomunikasi dengan orang lain (intrapesonal), orang tersebut sebenarnya berkomunikasi dengan dirinya sendiri terlebih dahulu. Komunikasi intrapesonal menunjang dan menopang semua komunikasi setiap individu (Nabilah, 2019).

Sebagai sebuah ilmu komunikasi, komunikasi intrapersonal sering sekali 
Volume 2, Nomor 2, Desember 2021

dihubungkan dengan konsep diri seseorang. Konsep diri terdiri dari dua macam yakni konsep diri positif dan negatif. Konsep diri mempengaruhi setiap aspek pada kehidupan manusia, termasuk hubungan antar individu, kemampuan fungsional seseorang dan juga kesehatan seseorang. Setiap individu memiliki konsep diri yang berbeda-beda yang membuat individu tersebut menjadi unik (Delaune \& Ladner dalam Sofiana et al., 2012)

Dari latar belakang di atas penulis berusaha untuk melihat bagaimana komunikasi intrapersonal dapat menjadi Self Healing, karena dari pengamatan penulis belum banyak yang meneliti tentang komunikasi intrapersonal sebagai media untuk penyembuhan diri (self Healing) dari suatu penyakit. Penulis melakukan penelitian ini karena di masa pandemic covid-19 pemberitaan di berbagai media menyebabkan ketakutan, dan kecemasan kepada masyarakat namun jarang atau bahkan tidak ada media yang memberitakan tentang bagaimana cara agar tetap tenang serta optimis menghadapi berbagai macam penyakit seperti covid-19 dan varian-variannya.

\section{METODE PENELITIAN}

Penelitian ini merupakan penelitian yang menggunakan pendekatan kualitatif dengan tipe penelitian yang digunakan ialah studi pustaka (library research). Studi pustaka yaitu pengumpulan data yang berkaitan dengan objek penelitian atau pengumulan data yang bersifat literatur (kepustakaan), baik dari bukubuku, karya tulis ilmiah terdahulu dan dokumen lainnya yang relevan dengan masalah pada penelitian ini.

\section{HASIL DAN PEMBAHASAN}

Komunikasi intrapersonal adalah komunikasi yang berlangsung kepada diri sendiri, diri sendiri sebagai komunikator dan diri sendiri juga sebagai komunikannya. Rakhmat dalam (Nabilah, 2019) mengungkapkan bahwa aktivitas komunikasi intrapersonal yang dilakukan sehari-hari antara lain ialah berdo'a, bersyukur, instrospeksi diri dan reaksi dari hati nurani, mendayagunakan kehendak diri yang bebas, berimajinasi dan lain sebagainya.

Berpikir sebagai salah satu proses dari komunikasi intrapersonal memiliki peran penting sebagai alat pengendali kehidupan jasmani. Pandangan spiritual (upanishad) berpendapat bahwa pikiran hanya bersifat maya adanya, pikiran ialah ilusi di mana tempat baik dan buruk berada, tempat dualisme tercipta, itulah mengapa pikiran juga disebut sebagai manomaya kosha. Pikiran dan badan jasmani bukanlah dua 
hal yang terpisah namun satu kesatuan yang saling mendukung dan saling mempengaruhi satu sama lainnya. Keduanya merupakan perpaduan maya yang keberadaannya adalah palsu tetapi ketika manusia menjalani kehidupan jasmaninya maka keduanya menajadi sangat penting (Arta, 2020).

Berkomunikasi dengan diri dilakukan setiap menerima informasi dari luar, penerimaan informasi dari luar akan menghasilkan sebuah feedback baik positif ataupun negatif. Kecemasan berlebih terhadap pesan yang diterima dari media pemberitaan tentang bahaya dari covid-19 cukup untuk membuktikan bahwa media dapat mempengaruhi pikiran manusia melalui informasi yang mengerikan tersebut. Namun pesan tersebut juga akan diproses oleh pikiran melalui komunikasi intrapesonal tergantung si penerima pesan memprosesnya menjadi pesan yang positif atau pesan yang negatif. Pastinya dampak yang dihasilkan dari pikiran yang positif akan menghasilkan tubuh yang sehat pula bagi manusia dan dampaknya pada manusia ialah jangka panjang (Arta, 2020).

Pada penelitiannya yang berjudul Meditasi Sebagai Mind Body Medicine Arta (2020) menyimpulkan bahwa "Meditasi sebagai sebuah teknik mampu memberikan berbagai efek positif terhadap seseorang yang disebut sebagai efek plasebo. Efek plasebo bekerja melalui perubahan-perubahan pada persepsi serta keyakinan seseorang. Melalui praktek meditasi maka seseorang akan lebih mampu untuk melihat kehidupannya sebagai hal yang positif sehingga dalam hal ini maka meditasi menjadi moderat positif antara pikiran serta tubuh manusia atau dikenal juga dengan sebutan mind body medicine". Jadi, meditasi sebagai salah satu komunikasi intrapersonal mampu menjadi sarana untuk self healing, karena mampu menciptakan pikiran positif dalam diri seseorang. Selain itu dengan meditasi seseorang akan memfokuskan pikiran. Sedangkan pikiran sendiri merupakan proses akhir dari komunikasi intrapersonal dan juga proses yang paling berpengaruh dari yang lainnya seperti sensasi, persepsi, dan memori.

Keyakinan manusia bertindak seperti filter pada kamera, mengubah cara pandang manusia melihat dunia kemudian tubuh (biologi) manusia akan beradaptasi dengan keyakinan yang mereka yakini. Ketika manusia benar-benar menyadari bahwa keyakinannya sangat kuat, maka ia memegang kunci kebebasan. Meskipun ia tidak dapat dengan mudah mengubah kode genetik mereka, tapi manusia dapat mengubah pikirannya. Seseorang yang berjalan melewati bara api tidak terbakar saat melewatinya karena memiliki 
keyakinan yang tinggi bahwa mereka tidak akan terbakar (Lipton, 2019).

Ketika seseorang meyakini terhadap informasi yang mereka terima baik itu positif ataupun negatif maka seseorang akan menciptakan efek kepada tubuhnya sesuai dengan informasi yang mereka yakini. Seperti itu juga proses self healing. Seseorang dapat sembuh dengan dokter A namun tidak dengan dokter B karena ia telah memprogram pikiran mereka bahwa dengan dokter A ia akan sembuh, meskipun obat yang diberikan kedua dokter tersebut sama persis. Lipton (2019) dalam penelitiannya menemukan bahwa efek penanganan palsu dengan menanamkan dan memberi keyakinan yang positif (placebo effect) kepada pasien memiliki efisiensi yang sama seperti efek dari obat kimia sebenarnya. Namun sebaliknya, bahwa nocebo effect (memberi keyakinan yang negatif) juga memiliki dampak yang sama kuatnya dengan placebo effect, ditemukan pasien yang yang lebih cepat meninggal setelah pasien tersebut dinyatakan umurnya tidak akan lebih dari enam bulan lagi karena sakit kanker yang ia diderita. Sedangkan hasil lab menyatakan bahwa kanker yang diderita pasien ternyata tidak terlalu parah dan tidak akan membawa dampak kematian.
Mason dokter muda Inggris (dalam Lipton, 2019) pada tahun 1952 mengobati kutil anak laki-laki berusia lima belas tahun dengan menggunakan hipnosis, padahal oleh dokter bedah penyakit kulit yang diderita anak tersebut tidak dapat disembuhkan karena penyakit yang ia derita merupakan penyakit genetika mematikan. Setelah itu Mason terkenal oleh pemberitaan media, banyak orang yang meminta pengobatan yang sama, tetapi hal tersebut tidak berhasil. Ketidak berhasillannya disangkutkan dengan perlakuannya dengan anak sebelumnya, karena saat dia berhasil ia merasa sombong dengan kemampuan yang ia punya. Namun, setelah kegagalannya, Mason menemukan bahwa pikiran dapat mempengaruhi program genetika manusia karena saat mengobati penyakit kulit anak berusia lima tersebut Mason tidak tahu bahwa itu merupakan penyakit genetika mematikan yang tidak dapat disembuhkan.

Sejalan dengan hal di atas, komunikasi intrapersonal juga berperan dalam kesehatan tubuh dan semangat dalam menjalani kehidupan. Seperti contoh, di kehidupan sehari-hari seseorang akan bersemangat melakukan pekerjaan dengan motivasi mendapatkan bonus dari atasan, namun sebaliknya seseorang akan bermalas-malasan ketika disuruh atasan tanpa ada imbalan apa-apa. Artinya pikiran 
berkomunikasi dengan cara mengirimkan sinyal positif kepada tubuh untuk bersemangat karena mendapatkan bonus dari atasan dan sebaliknya, ia akan mengirim sinyal negatif ketika tidak mendapatkan apa-apa. Placebo effect sama seperti efek yang ditimbulkan dari beritaberita di media tentang dampak-dampak kesehatan dan kematian yang disebabkan oleh covid-19, efek dari pemberitaan tersebut memiliki efek negatif terhadap kesehatan karena orang-orang hidup dipenuhi dengan kecemasan, dan ketakutan di mana ketika kita ditumbuhi rasa takut dan cemas malah akan membunuh berjuta-juta sel di dalam tubuh seperti yang dicetuskan oleh Lipton pada bukunya yang berjudul Biology Of Belief.

Penelitian selanjutnya yaitu dilakukan oleh (Rahmawati \& Muljohardjono, 2016) dengan judul 'Meaning of Illness dalam Perspektif Komunikasi Kesehatan dan Islam. Hasil yang ditemukan dalam penelitian mereka ialah makna sakit digolongkan menjadi dua yakni makna positif dan makna negatif. Makna positif akan terbentuk apabila penderita menerima sakitnya, optimis bahwa ia akan sembuh, serta menganggap sakit yang ia derita merupakan sesuatu yang biasa dan sebaliknya bagi si penderita yang memiliki makna negatif terhadap sakit yang ia derita maka ia akan memunculkan sikap terhadap pemaknaan diri yang tidak berdaya, lemah, tidak dapat berbuat apa- apa dan kehilangan semangat hidup. Artinya bahwa pemaknaan yang di proses oleh pikiran melalui komunikasi intrapersonal akan meberikan dampak yang baik pula. Jika seseorang yang sakin memiliki pikiran yang negatif terhadap apa yang dideritanya maka pikiran tersebut juga akan menghambat Kesehatan, dan apabila seseorang memberikan pikiran positif terhadap apa yang sudah diderita dan menganggapnya kehendak Tuhan Yang Maha Esa maka si penderita akan cepat membaik pula. Inia da hubungannya denga napa yang di jelaskan Lipton pada bukunya, jika pikiran memancarkan keyyakinan yang positif maka tubuh akan memperbaiki sel-sel tubuh pula.

Geist (dalam Rahmawati \& Muljohardjono, 2016) menjelaskan bahwa pesan yang dikirim dan diterima berisi tentang kesehatan, sakit, penyakit dan pengobatan maka disebut komunikasi Kesehatan. Komunikasi Kesehatan juga berhubungan erat dengan komunikasi intrapersonal karena melibatkan diri sebagai pengirim dan penerima pesan sehingga dapat dikatakan bahwa komunikasi intrapersonal sangat mempengaruhi kesehatan seseorang dari cara ia memproses informasi yang diterima. 
Komunikasi intrapersonal sebelum diterima sebagai pesan ia akan melalui proses di mana proses yang pertama ialah sensasi. Sensasi menurut Rakhmat (dalam Rahmawati \& Muljohardjono, 2016) ialah suatu tahapan di mana informasi diterima melalui panca indra. Pada tahap ini seseorang akan menerima informasi dari apa yang ia lihat dan dengar dari media maupun dari komunikator langsung. Seperti contoh, seseorang yang menerima informasi tentang covid-19. Pada tahap ini orang tersebut akan menerimanya atau akan mengabaikan informasi tersebut.

Kemudian tahap selanjutnya ialah persepsi, pada tahap ini apabila seseorang menerima informasi yang ia lihat atau dengarkan maka akan memberikan pemaknaan terhadap informasi tersebut. Persepsi juga dipengaruhi oleh harapan (expectation), motivasi, perhatian (attention), dan juga ingatan. Contohnya, apabila ia menerima pesan tentang bahaya, serta dampak, yang ditimbulkan covid-19 selanjutnya ia akan memaknai bagaimana covid-19 tersebut. Biasanya orang akan menerima dan memaknai sesuai apa yang ia inginkan. Seseorang olahragawan akan menganggap covid-19 tidak berbahaya apabila ia selalu menjaga pola hidup sehat, seseorang yang religious akan memaknai bahwa covid-19 adalah bentuk penghapusan dosa, tanda-tanda akhir zaman dan lain sebagainya.

Selanjutnya yaitu tahapan memori, tahapan ini dibagi menjadi tiga proses yaitu encoding (perekaman), Stroge (penyimpanan), dan retrievel (Pemanggilan). Informasi yang direkam akan disimpan dalam memori, kemudian informasi tersebut dapat dunduh kembali. Salah satu contohnya ialah hal-hal yang menyakitkan yang pernah dialami meskipun sudah puluhan tahun mampu kita ingat kembali karena informasi tersebut telah masuk ke dalam memori. Memori ini menyimpan banyak informasi yang pernah dialami seseorang baik yang menyenangkan maupun yang tidak menyenangkan. Tetapi pada kebanyakan kasus memori lebih cepat mengingat hal yang tidak menyenangkan daripada hal yang menyenangkan, orang seperti memiliki tipe neurotisme tinggi biasanya orang seperti ini akan lebih cepat memanggil ingatan negatif dalam memorinya orang yang neurotismenya rendah (Rahmayanti Prabowo, 2018).

Tahapan terakhir dari komunikasi intrapersonal ialah berpikir. Proses ini merupakan proses yang mempengaruhi dari ketiga proses sebelumnya dan merupakan proses yang berperan penting atas informasi yang diterima. Proses berpikir gunanya ialah untuk memahami 
realitas yang terjadi untuk mengambil keputusan, memecahkan suatu permasalahan, serta menghasilkan sesuatu yang baru. Berpikir berfungsi untuk mengolah informasi dan memanipulasi informasi agar memenuhi kebutuhan yang diinginkan atau memberikan respon terhadap informasi tersebut (Nabilah, 2019). Proses ini menjadi penentu karena informasi yang diterima akan sepenuhnya tersimpan sesuai denga apa yang dipikirkan. Apabila yang ada dalam pikiran bersifat positif maka informasi tersebut akan tersimpan dalam bentuk informasi yang positif pula dalam jangka waktu yang cukup panjang serta mempengaruhi konsep diri yang psoitif pula. Namun sebaliknya, apabila informasi yang diperoleh dari pikiran bersifat negatif maka konsep diri akan ikut negatif pula.

Dari uraian di atas dapat ditarik kesimpulan bahwa agar komunikasi intrapersonal dapat menjadi self healing ialah dengan cara memberikan respon positif terhadap informasi yang diterima, baik itu informasi positif maupun informasi negatif. Apabila kita dapat mengelola informasi menjadi respon yang positif itu artinya kita menyimpan hal positif di dalam memori kita. Informasi positif yang kita simpan tersebut dapat mempengaruhi konsep diri yang positif, dapat memberikan kesehatan bagi tubuh.
Seperti yang sudah dibahas sebelumnya, bahwa pikiran kita dapat menghidupkan sel-sel dalam tubuh dan dapat menyembuhkan penyakit genetika mematikan sekalipun. Self healing juga dapat dilatih dengan cara melakukan afirmasi agar nilai-nilai positif dapat disimpan dalam memori kita.

\section{KESIMPULAN}

Komunikasi intrapersonal sebagai self healing dapat dilakukan dengan cara menanamkan pikiran positif kepada diri kita. Meskipun informasi yang didapat merupakan informasi negatif tetapi tetap harus berpikir positif agar tubuh dapat merespon hal positif pula karena informasi negatif dapat berubah positif apabila kita menanamkan hal positif pada pikiran kita.

Saran penulis, kita sebagai makhluk sosial harus selalu menganalisa informasi yang kita dapat dari luar dengan baik dan selalu berpikiran positif agar jasmani maupun rohani kita dapat berjalan secara baik pula. Pada dasarnya permaslahan kita sendirilah yang menciptakannya dan kita pula yang harus menyelesaikannya dengan menanamkan nilai-nilai positif.

\section{DAFTAR PUSTAKA}

Lipton, B. H. (2019). Biology Of Belief. Tangerang Selatan: Javanica.

Arta, I. K. Y. (2020). Meditasi sebagai Mind Body Medicine. Sanjiwani: Jurnal Filsafat, 10(2), 165. doi:10.25078/sjf.v10i2.1516

Bahrien, B., \& Ardianty, S. (2017). 
Volume 2, Nomor 2, Desember 2021

Pengaruh Efektivitas Terapi Self Healing Menggunakan Energi Reiki terhadap Kecemasan Menghadapi Ujian Skripsi. Psympathic: Jurnal Ilmiah Psikologi, 4(1), 141-148. doi:10.15575/psy.v4i1.1227

Jamil, S., \& Appiah-Adjei, G. (2020). Battling with infodemic and disinfodemic: the quandary of journalists to report on COVID-19 pandemic in Pakistan. Media Asia, 47(3-4), 88-109. doi:10.1080/01296612.2020.1853393

Lipton, B. H. (2019). Biology Of Belief. Tangerang Selatan: Javanica.

Nabilah, B. (2019). Peranan Komunikasi Intrapersonal Dalam Proses Pembentukan Konsep Diri Dan Perilaku Mahasiswa Ilmu Komunikasi Universitas Sumatera Utara. Universitas Sumatera Utara.

Rahmawati, P., \& Muljohardjono, $\mathrm{H}$. (2016). Meaning of Illness dalam Perspektif Komunikasi Kesehatan dan Islam. Jurnal Komunikasi Islam, 6(2), 319-331.

Rahmayanti Prabowo, I. (2018). Perbedaan Kemampuan Short Term Memory Ditinjau Dari Tipe Kepribadian Introvert Dan Ekstrovert Pada Mahasiswa. Universitas Muhammadiyah Malang.

Sofiana, L. I., Elita, V., \& Utomo, W. (2012). Hubungan Antara Stress Dengan Konsep Diabetes Mellitus Tipe 2. Jurnal Ners Indonesia, 2(2), 167-176.

Tita Menawati, L., \& Hendra, K. (2015). Pentingnya Komunikasi Dalam Pelayanan Kesehatan Primer (Vol. 15). Nabilah, B. (2019). Peranan Komunikasi Intrapersonal Dalam Proses Pembentukan Konsep Diri Dan Perilaku Mahasiswa Ilmu Komunikasi Universitas Sumatera Utara. Universitas Sumatera Utara 